\title{
The Proinflammatory Cytokines Interleukin-I beta and Tumor Necrosis Factor-Alpha Activate Serotonin Transporters
}

\author{
Chong-Bin Zhu', Randy D Blakely ${ }^{1,2,3}$ and William A Hewlett*,1,2 \\ 'Department of Pharmacology, Vanderbilt University School of Medicine, Nashville, TN, USA; ${ }^{2}$ Department of Psychiatry, Vanderbilt University \\ School of Medicine, Nashville, TN, USA; ${ }^{3}$ Center for Molecular Neuroscience, Vanderbilt University School of Medicine, Nashville, TN, USA
}

\begin{abstract}
Proinflammatory cytokines and serotonergic homeostasis have both been implicated in the pathophysiology of major psychiatric disorders. We have demonstrated that activation of p38 mitogen-activated protein kinase (MAPK) induces a catalytic activation of the serotonin transporter (SERT) arising from a reduction in the SERT $K_{m}$ for 5 -hydroxytryptamine (5-HT). As inflammatory cytokines can activate P38 MAPK, we hypothesized that they might also activate neuronal SERT. Indeed, Interleukin- I beta (IL-I $\beta$ ) and tumor necrosis factor alpha (TNF- $\alpha$ ) stimulated serotonin uptake in both the rat embryonic raphe cell line, RN46A, and in mouse midbrain and striatal synaptosomes. In RN46A cells, IL-I $\beta$ stimulated 5-HT uptake in a dose- and time-dependent manner, peaking in $20 \mathrm{~min}$ at I00 ng/ml. This was abolished by IL-I ra $(20 \mathrm{ng} / \mathrm{ml})$, an antagonist of the IL-I receptor, and by SB203580 $(5 \mu \mathrm{M})$, a p38 MAPK inhibitor. TNF- $\alpha$ also dose- and time-dependently stimulated 5-HT uptake that was only partially blocked by SB203580. Western blots showed that IL- I $\beta$ and TNF- $\alpha$ activated P38 MAPK, in an SB203580-sensitive manner. IL-I $\beta$ induced an SB203580-sensitive decrease in 5-HT $K_{m}$ with no significant change in $V_{\max }$. In contrast, TNF- $\alpha$ stimulation decreased 5-HT $K_{m}$ and increased SERT $V_{\max }$. SB203580 selectively blocked the TNF- $\alpha$-induced change in SERT $K_{\mathrm{m}}$. In mouse midbrain and striatal synaptosomes, maximal stimulatory effects on 5-HT uptake occurred at lower concentrations (IL-I $\beta, 10 \mathrm{ng} / \mathrm{ml}$; TNF- $\alpha, 20 \mathrm{ng} / \mathrm{ml}$ ), and over shorter incubation times (I 0 min). As with RN46A cells, the effects of IL-I $\beta$ and TNF- $\alpha$ were completely (IL- I $\beta$ ) or partially (TNF- $\alpha$ ) blocked by SB203580. These results provide the first evidence that proinflammatory cytokines can acutely regulate neuronal SERT activity via p38 MAPK-linked pathways.

Neuropsychopharmacology (2006) 31, 2121-2131. doi:10.1038/sj.npp. I 301029; published online I February 2006
\end{abstract}

Keywords: serotonin; transporter; cytokines; IL- I $\beta$; TNF- $\alpha$; P38 MAPK

\section{INTRODUCTION}

The role of the immune mediators in the pathogenesis of neuropsychiatric disorders has drawn significant interest over the last decade. Elevated proinflammatory cytokines levels have been found in a number of psychiatric conditions. High levels of tumor necrosis factor alpha (TNF- $\alpha$ ) have been found in cerebral spinal fluid samples drawn from patients with obsessive-compulsive disorder (OCD), attention-deficit hyperactivity disorder, and schizophrenia (Mittleman et al, 1997). Likewise, serum levels of proinflammatory interleukins IL- $1 \beta$, IL-6, and TNF- $\alpha$ are elevated in depressed patients (Maes, 1999; Tuglu et al, 2003). Conversely, therapeutic treatments with proinflammatory cytokines result in 'sickness behavior' that is similar in many respects to depression, with decreased appetite,

\footnotetext{
*Correspondence: Dr WA Hewlett, Department of Psychiatryl Pharmacology, Vanderbilt School of Medicine, Nashville, TN $37232-$ 8645, USA, Tel: + I 6I5343 0795, Fax: + I 6153225298 ,

E-mail: william.a.hewlett@vanderbilt.edu

Received 2 September 2005; revised 16 November 2005; accepted 28 November 2005

Online publication: 21 December 2005 at http://www.acnp.org/ citations/Npp 122 1 05050549/default.pdf
}

anorexia, weight loss, fatigue, loss of libido, sleep disturbances, and reduced social contact (Kent et al, 1996; Yirmiya et al, 2000; Dantzer, 2001), and depression is frequently observed in association with peripheral inflammatory cytokine activation in a number of medical conditions including viral infections, rheumatoid arthritis, cancer, and neurodegenerative diseases (Meijer et al, 1988; Hall and Smith, 1996; Yirmiya et al, 1999; Pollak et al, 2000). Additionally, in human volunteers, depression, anxiety, and memory impairment are associated with immune activation by the bacterial endotoxin, lipopolysaccharide, and are correlated with serum IL- $1 \beta$ and TNF- $\alpha$ levels induced by that treatment (Yirmiya et al, 2000).

Although the studies noted above suggest a correlation between immune activation and psychiatric symptoms, the underlying mechanisms for such a relationship have not been established. Peripheral cytokines have access to the CNS (Schiepers et al, 2005), and both IL-1 $\beta$ and TNF- $\alpha$ are expressed in the brain (Botchkina et al, 1997; Rivest et al, 2000; Sheng et al, 2001; Bette et al, 2003). Inflammatory cytokines are known to alter metabolism and release of central serotonin (5-hydroxytryptamine, 5-HT) in the CNS (Dunn, 1992; Palazzolo and Quadri, 1992; Cho et al, 1999). $5-\mathrm{HT}$ is a neurotransmitter involved in the regulation of a 
wide array of behaviors including those related to sleep, appetite, aggression, and mood (Nestler et al, 2001). Medications that modulate serotonergic signaling are used to treat many psychiatric disorders including eating disorders, depression, anxiety, OCD, impulse control disorders, and schizophrenia.

A primary target for serotonergic medications has been the 5-HT transporter (SERT, 5-HTT), a protein involved in termination of serotonergic signaling (Barker and Blakely, 1995). These medications block reuptake of serotonin into the serotonergic neuron, and thereby increase the available serotonin for postsynaptic interactions. Alterations in SERT expression and activity associated with variations in the human SERT gene have been associated with mental illness (Murphy et al, 2003). One genetic variant associated with elevated SERT activity has been associated with OCD as well as other psychiatric disturbances (Ozaki et al, 2003), whereas altered SERT expression associated with a different variant has been found to predispose individuals to depression and suicidal disorders (Caspi et al, 2003). Recently, we identified multiple SERT coding variants in autistic probands, and associated these variants with rigidcompulsive behavioral traits (Sutcliffe et al, 2005). As such, it is clear that modulation of SERT activity has profound implications in terms of emotional homeostasis.

Although the psychiatric effects of genetic disturbances in SERT activity have attracted significant attention, acute regulation of SERT activity by neurotransmitters and modulators has only been studied more recently using in vitro models that have revealed neurotransmitter receptor-linked intracellular cascades modulating 5-HT uptake. Protein kinase C (PKC) activation and protein phosphatase $2 \mathrm{~A}$ inhibition trigger transporter phosphorylation, events that are correlated with a loss of SERT surface density (Qian et al, 1997; Ramamoorthy et al, 1998; Ramamoorthy and Blakely, 1999). Alpha-2 adrenergic receptor stimulation leads to a rapid downregulation of SERT activity in brain synaptosomes (Ansah et al, 2003), whereas histamine receptor stimulation induces protein kinase G (PKG)-linked increases in 5-HT transport in platelets. Miller and Hoffman (1994) demonstrated that adenosine receptor (AR) stimulation in rat basophilic leukemia cells (RBL-2H3) also leads to a PKG-linked increase in SERT activity. Using this RBL-2H3 cell model, as well as AR/SERT co-transfected CHO cells, we recently found that this PKG-linked increase in 5-HT uptake occurs via distinct SERT trafficking-dependent and traffickingindependent pathways (Zhu et al, 2004). Specifically, we found that PKG could activate p38 mitogen-activated protein kinase (MAPK) to catalytically activate SERT in a process independent of PKG-mediated trafficking of SERT to the plasma membrane (Blakely et al, 2005; Zhu et al, 2005). The catalytic activation of SERT was the result of a reduction in the SERT $K_{\mathrm{m}}$ for $5-\mathrm{HT}$, making the transporter more efficient at lower 5-HT concentrations. In RBL-2H3 and a serotonergic rat embryonic raphe cell line (RN46A; Eaton and Whittemore, 1996), we further demonstrated that activation of p38 MAPK by a variety of stimulus modalities (anisomycin, $\mathrm{H}_{2} \mathrm{O}_{2}$, UV radiation) enhanced 5-HT transport (Zhu et al, 2005). Saturation kinetic analyses revealed that p38 MAPK activation was associated with a selective reduction in 5-HT $K_{\mathrm{m}}$ accompanied by an increase in
5-HT potency in displacing surface SERT antagonist binding. Consistent with these changes, stimulation of p38 MAPK with anisomycin enhances SERT activity without altering surface SERT density.

As proinflammatory cytokines such as IL- $1 \beta$ and TNF- $\alpha$ were known to activate p38 MAPK in peripheral systems (Clerk et al, 1999; Saklatvala, 2004; Li et al, 2005; Pantouli et al, 2005), we hypothesized that these cytokines might acutely increase SERT activity through p38 MAPK activation, and might provide a critical link to physiologically significant systems known to regulate SERT in vivo. To this end, we examined the effects of IL- $1 \beta$ and TNF- $\alpha$ on serotonin uptake in the RN46A cell line. In addition, as both IL- $1 \beta$ and TNF- $\alpha$ are present in the brain, we examined the effects of these cytokines on serotonin transport in synaptosomal preparations from mouse midbrain and striatum. These regions allowed us to investigate alterations in SERT activity in the vicinity of the 5-HT-cell soma, and within an important distal terminal field, respectively. We provide evidence that IL- $1 \beta$ and TNF- $\alpha$ activate $5-\mathrm{HT}$ transport in a p38 MAPK-sensitive manner, and do so via catalytic modulation (deceased $K_{\mathrm{m}}$ ) of the SERT protein.

\section{MATERIALS AND METHODS}

\section{Reagents}

Interleukin-1beta (IL-1 $\beta$ ), interleukin-1 receptor antagonist (IL-1ra), and tumor necrosis factor-alpha (TNF- $\alpha$ ) were purchased from Santa Cruz Biotechnology Inc. (Santa Cruz, CA); anisomycin was ordered from Sigma Chemical (St Louis, MO). SB203580 was obtained from Alexis Biochemicals (San Diego, CA). Anti-total and -phosphospecific p38 MAPK polyclonal antibodies were purchased from Cell Signaling (La Jolla, CA). $\left[{ }^{3} \mathrm{H}\right] 5-\mathrm{HT}$ (5-hydro$\mathrm{xy}\left[{ }^{3} \mathrm{H}\right]$ tryptamine trifluoroacetate, $\left.107 \mathrm{Ci} / \mathrm{mmol}\right)$ was purchased from Amersham Biosciences Inc. (Piscataway, $\mathrm{NJ}$ ); trypsin-EDTA, glutamine, and ampicillin/streptomycin were purchased from Invitrogen (Carlsbad, CA); modified Eagle's medium (MEM) and Dulbecco's MEM (DMEM) were derived from Invitrogen reagents and prepared in the Vanderbilt Media Core.

\section{Cell Culture and Synaptosomal Preparation}

RN46A cells (provided by Dr Whittemore, University of Miami School of Medicine, Miami, FL) were cultured at $37^{\circ} \mathrm{C}$ with DMEM : F12 (1:1 in volume) containing $250 \mathrm{mg} / \mathrm{l}$ G418, 10\% FBS, 1\% L-Gln, and $100 \mathrm{~g} / \mathrm{ml}$ penicillin/streptomycin. For the preparation of synaptosomes, C57BL/6NHSD mice (Harlan Sprague Dawley Inc., Indianapolis, IN) were used as approved by the Institutional Animal Care Use Committee at Vanderbilt University. Synaptosomes were prepared as previously described (Ansah et al, 2003). Briefly, mouse midbrain and striatum were homogenized in $0.32 \mathrm{M}$ glucose at 400 r.p.m. using a Teflon-glass tissue homogenizer (Wheaton Instruments, Millville, NJ). The homogenized tissue was centrifuged at $800 \mathrm{~g}$ for $10 \mathrm{~min}$ at $4{ }^{\circ} \mathrm{C}$. The supernatant was transferred to new clean centrifuge tubes and centrifuged at $10000 \mathrm{~g}$ for $15 \mathrm{~min}$ at $4^{\circ} \mathrm{C}$. The synaptosomal pellet was resuspended with KrebsRinger's HEPES (KRH) buffer containing $130 \mathrm{mM} \mathrm{NaCl}$, 
$1.3 \mathrm{mM} \quad \mathrm{KCl}, \quad 2.2 \mathrm{mM} \quad \mathrm{CaCl}_{2}, \quad 1.2 \mathrm{mM} \quad \mathrm{MgSO}_{4}, \quad 1.2 \mathrm{mM}$ $\mathrm{KH}_{2} \mathrm{PO}_{4}, 1.8 \mathrm{~g} / \mathrm{l}$ glucose, $10 \mathrm{mM}$ HEPES, pH 7.4, $100 \mu \mathrm{M}$ pargyline, and $100 \mu \mathrm{M}$ ascorbic acid. The synaptosomal suspension was analyzed for protein content (Bio-Rad protein assay reagents) and used for both 5-HT transport assay and Western blots.

\section{5-HT Transport Assays}

$\left[{ }^{3} \mathrm{H}\right] 5-\mathrm{HT}$ transport activity in RN46A cells was assayed as described previously (Zhu et al, 2005). Briefly, RN46A cells were plated at 200000 cells/well $24 \mathrm{~h}$ before the 5-HT uptake assay. The medium was removed by aspiration and cells were washed once with KRH buffer. Cells were incubated in triplicate at $37^{\circ} \mathrm{C}$ in $\mathrm{KRH}$ buffer $(0.2 \mathrm{ml} /$ well $)$ containing $100 \mu \mathrm{M}$ pargyline and $100 \mu \mathrm{M}$ L-ascorbic acid (Sigma), with or without modifiers. After $10 \mathrm{~min}$ incubation with $\left[{ }^{3} \mathrm{H}\right] 5$ HT (100 nM) at $37^{\circ} \mathrm{C}$, buffer was aspirated and the cells were washed three times with ice-cold KRH buffer. Cells were solubilized with $0.4 \mathrm{ml}$ Microscint 20 (Packard Bioscience, Meriden, CT), and tritium-labeled monoamine accumulation was quantitated using a TopCount plate scintillation counter (Packard Bioscience, Meriden, CT). Specific 5-HT uptake was determined by subtracting the amount of $\left[{ }^{3} \mathrm{H}\right] 5$ HT accumulated in the presence of $10 \mu \mathrm{M}$ paroxetine. 5-HT saturation kinetics in RN46A cells were defined as described for standard transport assays, using varying concentrations of $0.5 \mathrm{Ci} / \mathrm{mmol}\left[{ }^{3} \mathrm{H}\right] 5-\mathrm{HT}$ produced using unlabeled $5-\mathrm{HT}$. Nonspecific uptake was defined with $10 \mu \mathrm{M}$ paroxetine. Assays measuring transport of $\left[{ }^{3} \mathrm{H}\right] 5-\mathrm{HT}$ in synaptosome were performed as described (Ansah et al, 2003). Generally, $30-50 \mu \mathrm{g}$ synaptosomes per sample (a total volume of $200 \mu \mathrm{l})$ were preincubated at $37^{\circ} \mathrm{C}$ in a shaking water bath for $10 \mathrm{~min}$. Vehicle or modifiers were then added for $10-$ $60 \mathrm{~min}$. After $5 \mathrm{~min}$ incubation with $\left[{ }^{3} \mathrm{H}\right] 5-\mathrm{HT}(20 \mathrm{nM})$ at $37^{\circ} \mathrm{C}$, uptake was terminated by filtration through $\mathrm{GF} / \mathrm{B}$ Whatman paper. Filters were washed three times with icecold KRH buffer, immersed in scintillation liquid for $8 \mathrm{~h}$, and counted by scintillation spectrometry. Counts obtained from the filtered samples were corrected for the nonspecific uptake obtained using parallel samples incubated with paroxetine $(1 \mu \mathrm{M})$.

\section{Assays of p38 MAPK Activation}

To monitor activation of p38 MAPK by IL- $1 \beta$ or TNF- $\alpha$, RN46A cells were seeded in six-well plates (500 000 cells/ well) and cultured for $24 \mathrm{~h}$. Cells were washed once with KRH buffer followed by treatment with IL- $1 \beta$ or TNF- $\alpha$ in the presence or absence of SB203580 or relevant antagonist. Following the treatment, the $\mathrm{KRH}$ buffer containing modifiers was removed and cells were lysed with radioimmunoprecipitation assay (RIPA) buffer (10 mM Tris- $\mathrm{HCl}$, $\mathrm{pH}$ 7.5, $150 \mathrm{mM} \mathrm{NaCl}, 1 \mathrm{mM}$ EDTA, $0.1 \%$ SDS, $1 \%$ Triton X$100,1 \% \mathrm{Na}$-deoxycholic acid) containing protease inhibitor cocktails (Sigma). Cell lysates were centrifuged at $10000 \mathrm{~g}$ for $20 \mathrm{~min}$. For monitoring the activation of p38 MAPK in synaptosomes, an aliquot of synaptosomal suspension was centrifuged and lysed with RIPA buffer at different time points during incubation. Up to $50 \mu \mathrm{g}$ protein from RN46A supernatant or $100 \mu \mathrm{g}$ protein from the synaptosomal supernatant was mixed with Laemmli buffer $(62.5 \mathrm{mM}$ Tris
pH 6.8, 20\% glycerol, 2\% SDS, 5\% mercaptoethanol, and $0.01 \%$ bromophenol blue) and separated by SDS-PAGE, before transfer to PVDF membranes (Millipore, Bedford, $\mathrm{MA})$ at $25 \mathrm{~V}$ for $30 \mathrm{~min}$ using Trans-Blot ${ }^{\circledR}$ SD Semi-Dry Electrophoretic Transfer Cell (Bio-Rad, Hercules, CA). Blotted membranes were subsequently blocked with $5 \%$ non-fat dry milk in PBS with $0.1 \%$ Triton X-100 or Odyssey Blocking Buffer (Li-Cor Biosciences, Lincoln, NE), and probed with anti-total or phospho-p38 MAPK polyclonal antibodies (1:1000; Cell Signaling) in 5\% milk/PBS with $0.1 \%$ Triton X-100 or Odyssey Blocking Buffer, while gently shaking for $1 \mathrm{~h}$ at room temperature. Bound antibody was detected with HRP-conjugated goat anti-rabbit secondary antibody (for milk-blocked membrane, 1:10000; Jackson ImmunoResearch, West Grove, PA), or fluorescence-labeled secondary antibody-Alexa Fluor 680 (for Odyssey-blocked membrane, avoiding exposure to light; 1:5000 in Odyssey Blocking Buffer; Molecular Probes Inc., Eugene, OR) for $1 \mathrm{~h}$ at room temperature. HRP signals were developed with ECL-plus solution (Amersham). To estimate the relative abundance of proteins, films were scanned on an AGFA Duoscan T1200, and the captured images were analyzed in Adobe Photoshop and quantified with NIH Image software, taking care through multiple exposures to work in the linear range of the film. The membrane processed with Odyssey reagents was scanned, and the captured image of the signal was processed and quantified with the Odyssey ${ }^{\mathrm{TM}}$ Infrared Imaging System (Li-Cor Biosciences, Lincoln, NE).

\section{Statistical Analyses}

All experiments were performed at least three times. Statistical analyses, comparing baseline and compoundmodified uptake, or p38MAPK activation, were performed with GraphPad Prism (GraphPad, San Diego, CA) using one- and two-way analyses of variance (ANOVA) with subsequent planned comparisons (Dunnett, Bonferroni), as well as $t$-tests as noted in the legends.

\section{RESULTS}

\section{Stimulation of 5-HT Uptake in RN46A Cells by IL- $1 \beta$ and TNF- $\alpha$}

IL-1 $\beta$ exerted a concentration- and time-dependent stimulation of 5-HT transport activity in cultured RN46A cells (Figure 1a and $\mathrm{b}$ ). IL-1 $\beta$ stimulation of the 5-HT transport peaked at $100 \mathrm{ng} / \mathrm{ml}, \sim 180 \%$ of control levels at $20 \mathrm{~min}$, and declined to basal levels by $60 \mathrm{~min}$. Using $20 \mathrm{~min}$ pretreatment, IL- $1 \beta$ stimulation peaked at $100 \mathrm{ng} / \mathrm{ml}$ and diminished over $200 \mathrm{ng} / \mathrm{ml}$. Consistent with previous findings, the effects of IL-1 $\beta$ on 5 -HT uptake were blocked by preincubation with the p38 MAPK inhibitor, SB203580 (Figure 3). Similarly, TNF- $\alpha$ also induced 5-HT uptake in a concentration- and time-dependent manner (Figure 2a and b). At $100 \mathrm{ng} / \mathrm{ml}$, TNF- $\alpha$ stimulation of $5-\mathrm{HT}$ transport was transient, peaking at $20 \mathrm{~min}$ and declining to basal levels by $60 \mathrm{~min}$. At $20 \mathrm{~min}$ incubation, TNF- $\alpha$ stimulation peaked at $100 \mathrm{ng} / \mathrm{ml}$, diminishing at $1 \mu \mathrm{g} / \mathrm{ml}$. Unlike IL- $1 \beta$, the effect of TNF- $\alpha$ was only partially blocked by SB203580, indicating a more complicated mechanism underlying TNF- $\alpha$ action (Figure 3). 

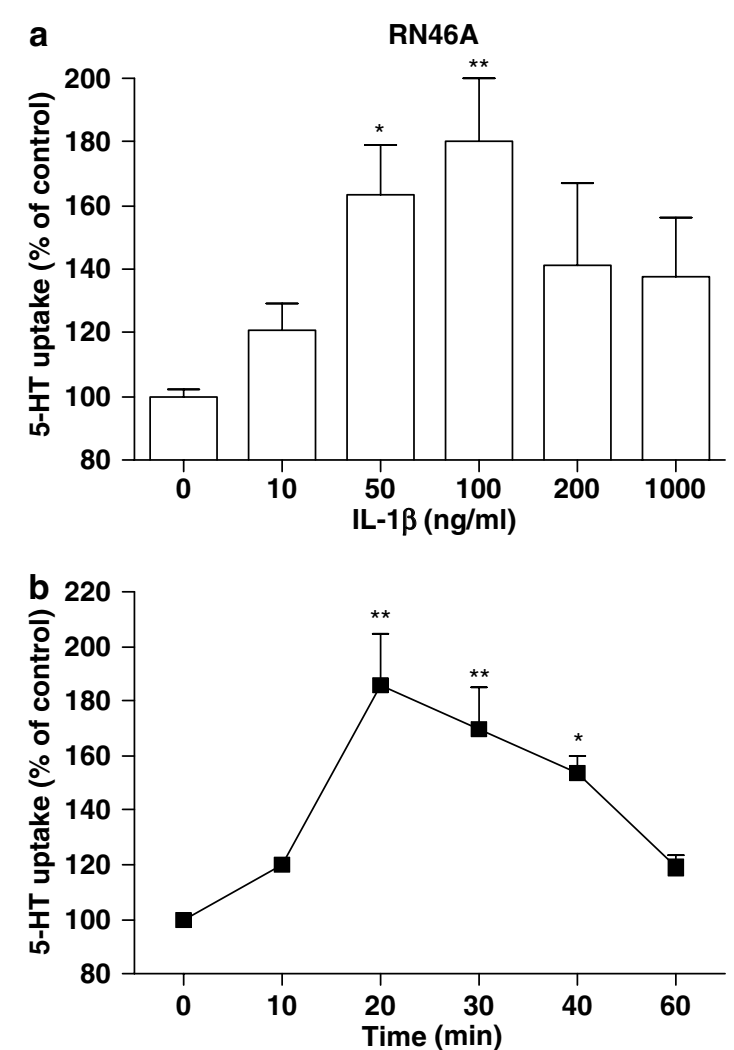

Figure I Effects of IL-I $\beta$ on 5-HT uptake in RN46A cells. (a) Dose response: Cells were treated with varying concentrations of $I L-\mid \beta$ for 20 min before transport assay. (b) Time course: Influence of pretreatment duration on IL- I $\beta(100 \mathrm{ng} / \mathrm{ml})$ stimulation of $5-\mathrm{HT}$ uptake. Values in (a) and (b) are expressed as the mean of at least three experiments \pm SEM. $* p<0.05, * * p<0.01$ vs controls (one-way ANOVA, Dunnett)

p38 MAPK must be dually phosphorylated to achieve catalytic activation (New and Han, 1998). To test whether IL- $1 \beta$ and TNF- $\alpha$ treatments of RN46A cells trigger p38 MAPK activation, we monitored the dualphosphorylation status of the kinase with total and phospho-specific p38 MAPK antibodies using Western blotting techniques. As shown in Figure $4 \mathrm{a}$ and $\mathrm{b}$, both IL-1 $\beta$ and TNF- $\alpha$ stimulated increases in phosphorylated p38 MAPK, effects that were blocked by pretreatment with SB203580. No changes were observed in total p38 MAPK levels.

\section{IL-1 $\beta$-Induced 5-HT Uptake is Abolished by IL-1 Receptor Antagonist in RN46A Cells}

The initial events in the signaling cascades triggered by these cytokines is the binding and activation of specific receptors for TNF- $\alpha$ and IL-1 cytokines (Stauber et al, 1988; Hohmann et al, 1989; Brockhaus and Loetscher, 1990; Sims et al, 1988; O'Neill and Dinarello, 2000). Whereas the IL-1 receptor antagonist, IL-1 ra, is commercially available, there is currently no such selective receptor antagonist available for TNF- $\alpha$ receptors. To assess whether IL- $1 \beta$ stimulates SERT activity via IL-1 receptors, IL-1 ra was preincubated with RN46A cells followed by treatment with IL-1 $\beta$. Anisomycin, a direct p38 MAPK stimulator and activator of SERT (Zhu et al, 2005), was used as a positive control
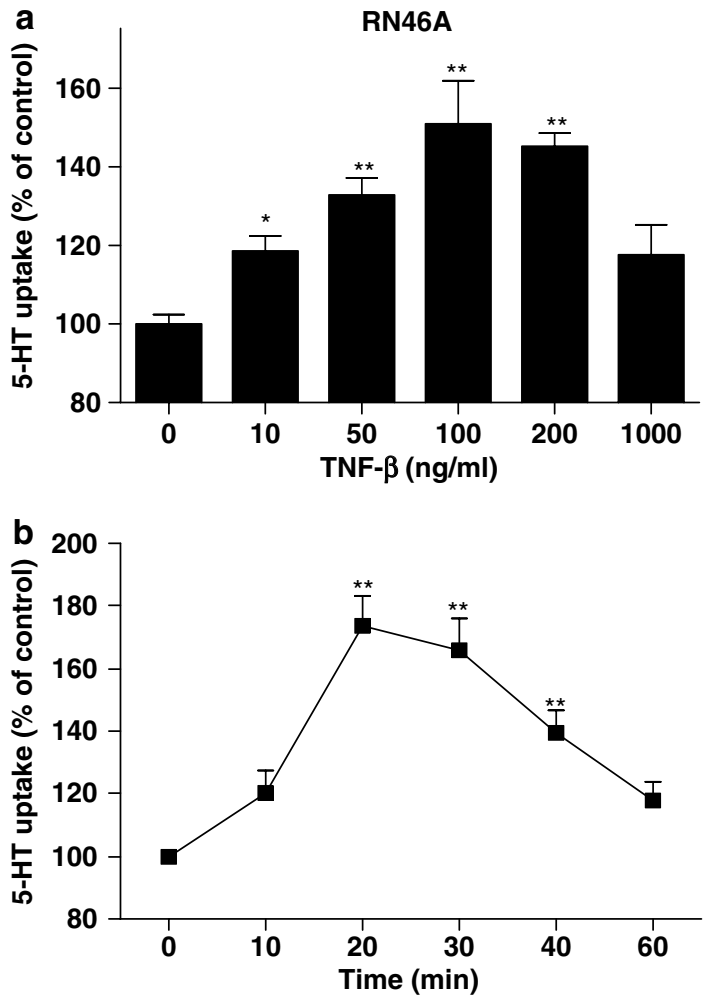

Figure 2 Effects of TNF- $\alpha$ on 5-HT uptake in RN46A cells. (a) Dose response: Cells were treated with the indicated concentrations of TNF- $\alpha$ for $20 \mathrm{~min}$ before transport assay. (b) Time course: Influence of pretreatment duration on TNF- $\alpha(100 \mathrm{ng} / \mathrm{ml})$ stimulation of $5-\mathrm{HT}$ uptake. Values in (a) and (b) are expressed as the mean of at least three experiments \pm SEM. $* p<0.05$, *** $p<0.01$ vs controls (one-way ANOVA, Dunnett).

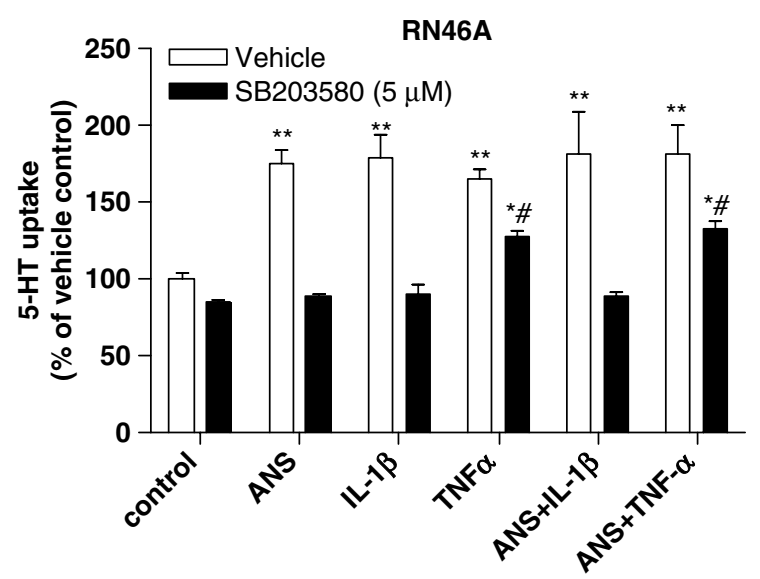

Figure 3 Effects of SB203580 on IL-I $\beta$ - or TNF- $\alpha$-stimulated 5 -HT uptake. RN46A cells were incubated with the specific p38 MAPK inhibitor SB203580 $(5 \mu \mathrm{M})$ or vehicle for $15 \mathrm{~min}$, followed by treatment with anisomycin ( $1.0 \mu \mathrm{M}), \mathrm{IL}-\mid \beta(\mid 00 \mathrm{ng} / \mathrm{ml})$, TNF- $\alpha(\mid 00 \mathrm{ng} / \mathrm{ml})$, or a combination of anisomycin and IL-I $\beta$ or TNF- $\alpha$. Values are expressed as mean values $(n=4) \pm$ SEM. ${ }^{*} p<0.05,{ }^{*} * p<0.0$ I vs vehicle control; ${ }^{\#} p<0.05$ vs TNF- $\alpha \pm$ anisomycin (two-way ANOVA). ANS: anisomycin; SB: SB203580.

that bypasses requirements for cell surface receptors. IL-1ra $(10 \mathrm{ng} / \mathrm{ml})$ blocked IL-1 $\beta$-stimulated 5 -HT transport, as did the p38 MAPK inhibitor SB203580 (Figure 5). In contrast, 
a

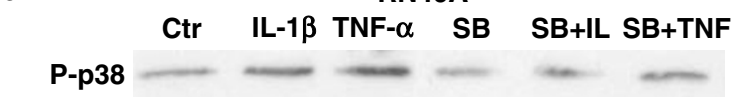

Total p38 $-\cdots \cdots$

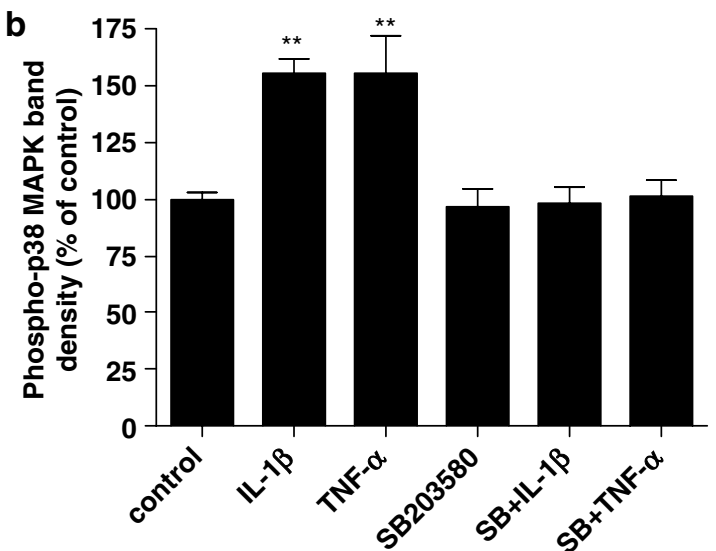

Figure $4 \mathrm{LL}-\mathrm{I} \beta$ or TNF- $\alpha$ triggers p38 MAPK phosphorylation in RN46A cells in an SB203580-sensitive manner. RN46A cells were seeded in a sixwell plate and cultured overnight. The cells were then treated with vehicle (assay buffer) or SB203580 (5 $\mathrm{MM})$ for $15 \mathrm{~min}$ followed by $20 \mathrm{~min}$ treatment with $\mathrm{IL}-\mathrm{I} \beta$ or TNF- $\alpha(100 \mathrm{ng} / \mathrm{ml}$ for each). The cells were then processed for activated and total p38 MAPK immunoblots as described in Materials and methods. (a) Representative blots of phosphorylated (top) and total p3 (bottom). (b) Average values of activated p38 immunoblots from densitometry of experiments $(n=3)$. Values are expressed as the mean \pm SEM. $* * * 0<0.01$ vs vehicle (one-way ANOVA, Dunnett).

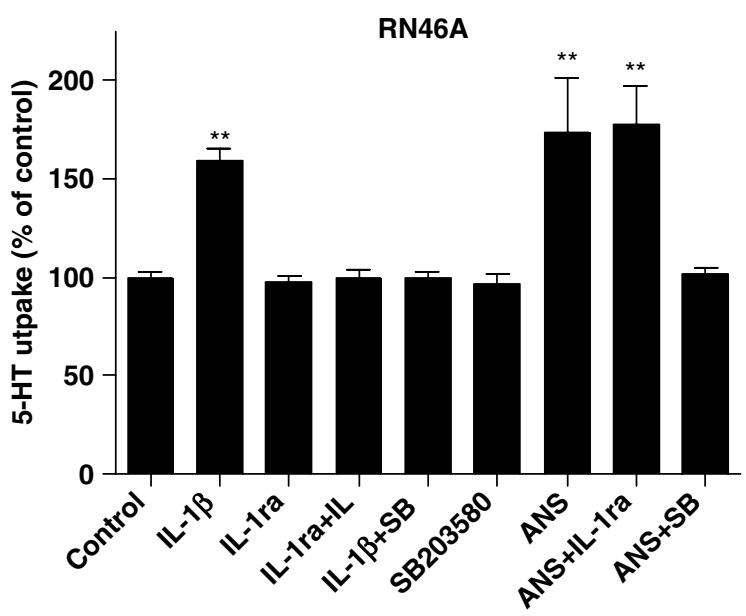

Figure 5 Effect of IL-I receptor antagonist on IL-I $\beta$-induced 5 -HT uptake. RN46A cells were treated for 10 min with the antagonist IL-I ra, SB203580, or vehicle, followed by IL-I $\beta$ (20 min) or anisomycin (I 0 min) treatment. IL- I ra $(10 \mathrm{ng} / \mathrm{ml})$ completely blocked IL- I $\beta$ - but not anisomycininduced 5-HT uptake. SB203580 (5 $\mu \mathrm{M})$ blocked the effect of both. Values are expressed as mean values $(n=3) \pm$ SEM. $* * * 0.01$ vs vehicle (oneway ANOVA, Dunnett). ANS: anisomycin; SB: SB203580.

whereas anisomycin-induced 5-HT uptake was abolished by SB203580, no attenuation was observed with IL-1ra (Figure 5), consistent with p38 MAPK being downstream of the IL-1 receptor.

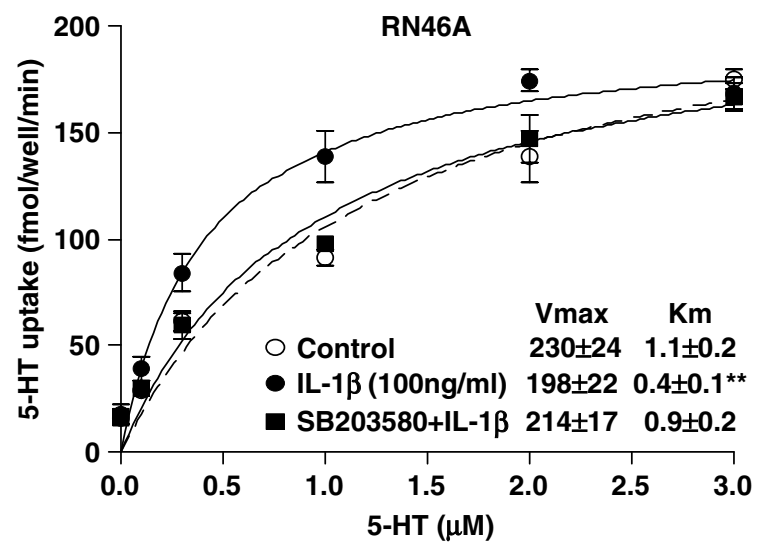

Figure 6 Saturation kinetic analyses of IL-I $\beta$ stimulation. RN46A cells were treated with vehicle or SB203580 (5 $\mu \mathrm{M})$ for I 5 min followed by ILI $\beta(\mid 00 \mathrm{ng} / \mathrm{ml})$ for $20 \mathrm{~min}$ before transport assays. Data were fit to a Michaelis-Menten equation (single binding site) to derive 5-HT $K_{m}$ and $V_{\max }$ values (expressed as mean values $\left.(n=3) \pm S E M\right)$. ${ }^{* *} p<0.0$ I vs control (Student's t-test).

\section{IL-1 $\beta$ Treatment of RN46A Cells Selectively Reduces the 5-HT-Transport $K_{\mathrm{m}}$}

Our recent study revealed that anisomycin-induced SERT stimulation does not arise from altered surface trafficking, but induces p38 MAPK-mediated catalytic activation of SERT (Zhu et al, 2005). Consistent with these findings, IL-1 $\beta$ treatments significantly reduced the SERT $K_{\mathrm{m}}$ for 5 - HT in RN46A cells $(1.1 \pm 0.2 v s 0.4 \pm 0.1 \mu \mathrm{M}, p<0.01)$, but effected no significant change in maximal transport capacity $\left(V_{\max }\right.$; Figure 6). Saturation kinetic analyses of 5-TH uptake revealed that incubation of RN46A cells with SB203580 before the treatment with IL-1 $\beta$ reversed the effects on $5-\mathrm{HT} K_{\mathrm{m}}$.

\section{TNF- $\alpha$ Stimulation of SERT Activity Involves Changes in Both $V_{\max }$ and $K_{\mathrm{m}}$ in 5-HT Transport}

To evaluate the impact of TNF- $\alpha$ on the $V_{\max }$ and $K_{\mathrm{m}}$ of 5-HT transport, RN46A cells were treated as above with vehicle or TNF- $\alpha$, with and without SB203580. Saturation kinetic analyses (Figure 7) showed that TNF- $\alpha$ treatment not only induced a reduction of $K_{\mathrm{m}}(0.7 \pm 0.11 v s 1.0 \pm 0.12 \mu \mathrm{M}$ in control), but also an increase in $V_{\max }$ of 5-HT transport $(394 \pm 33$ vs $294 \pm 22 \mathrm{fmol} / \mathrm{well} / \mathrm{min}$ in control). Notably, pretreatment with SB203580 blocked the shift of $K_{\mathrm{m}}$ $(1.1 \pm 0.21 \mu \mathrm{M})$, but did not affect significantly the increase of $V_{\max }(346 \pm 16 \mathrm{fmol} / \mathrm{well} / \mathrm{min})$. These results suggest that TNF- $\alpha$-induced 5-HT transport arises from a more complex form of stimulation than does IL- $1 \beta$-stimulated transport, although here as well, p38 MAPK activation accounts for the changes in $5-\mathrm{HT} K_{\mathrm{m}}$.

\section{Stimulation of 5-HT Uptake in Mouse Synaptosomes by IL- $1 \beta$ and TNF- $\alpha$}

To assess the relevance of our findings with cultured raphe cells for native brain systems, synaptosomes were prepared from midbrain and striatum of C57BL/6 mice and treated with IL- $1 \beta$ or TNF- $\alpha$. As seen in RN46A cells, the stimulation of 5-HT transport in synaptosomes induced by IL-1 $\beta$ or TNF- $\alpha$ was transient, peaking in this case at $10 \mathrm{~min}$ and diminishing $20 \mathrm{~min}$ after treatment in both 
midbrain and striatum (data not shown). Using $10 \mathrm{~min}$ pretreatment, IL-1 $\beta$ dose-dependently stimulated an increase in 5-HT uptake in both midbrain (Figure 8a) and striatum (Figure $8 \mathrm{c}$ ), peaking at $10 \mathrm{ng} / \mathrm{ml}$. At $100 \mathrm{ng} / \mathrm{ml}$, the IL-1 $\beta$ effect on SERT became inhibitory in both brain regions. This inhibition could represent a toxic effect; however, it was not investigated further. Treatment of synaptosomes with TNF- $\alpha$ for $10 \mathrm{~min}$ also induced an elevation in 5-HT transport in a concentration-dependent manner, with a maximal effect at $20 \mathrm{ng} / \mathrm{ml}$. Stimulation declined to basal levels at concentrations over $50 \mathrm{ng} / \mathrm{ml}$ (Figure $8 \mathrm{~b}$ and $\mathrm{d}$ ).

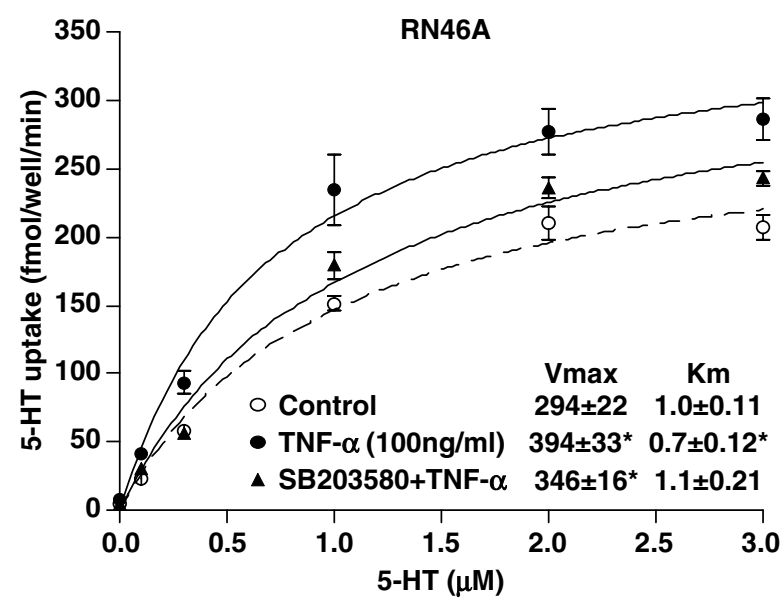

Figure 7 Saturation kinetic analyses of TNF- $\alpha$ stimulation. RN46A cells were treated with vehicle or SB203580 $(5 \mu \mathrm{M})$ for $15 \mathrm{~min}$ followed by TNF- $\alpha(100 \mathrm{ng} / \mathrm{ml})$ for $20 \mathrm{~min}$ before transport assays. Values are expressed as mean values $(n=3) \pm$ SEM. * $p<0.05$ vs control (Student's t-test). p38 MAPK is Involved in IL-1 $\beta$ - and TNF- $\alpha$-Stimulated 5-HT Transport in Mouse Synaptosomes

To assess p38 MAPK activation in synaptosomes, samples from mouse midbrain or striatum were preincubated with IL- $\beta$ or TNF- $\alpha$ in the presence/absence of p38 MAPKspecific inhibitor SB203580. As shown in Figure 9a, IL-1 $\beta$ stimulated an increase of 5-HT uptake in mouse midbrain. SB203580 pretreatment at this concentration $(1 \mu \mathrm{M})$ did not affect basal uptake, but at $5 \mu \mathrm{M}$ it reduced SERT activity. SB203580 blocked IL-1 $\beta$-induced 5-HT transport at both concentrations. As seen in RN46A cells, TNF- $\alpha$ stimulation of 5-HT uptake in midbrain was only partially blocked by SB203580 at a concentration $(1 \mu \mathrm{M})$ that did not affect basal 5 -HT uptake (Figure 9b), whereas TNF- $\alpha$ stimulation of uptake was abolished by SB203580 at $5 \mu \mathrm{M}$, a concentration that reduced basal uptake. In striatum, the 5-HT transport induced by either IL- $1 \beta$ or TNF- $\alpha$ was blocked by SB203580 at $5 \mu \mathrm{M}$ (Figure 9c). In addition, we observed that pretreatment of midbrain synaptosomes with IL- $1 \beta$ or TNF- $\alpha$ enhanced the phosphorylation of p38 MAPK, effects that were blocked by SB203580. Total p38 MAPK levels remained unchanged (Figure 10). We found similar effects of IL- $1 \beta$ or TNF- $\alpha$ on p38 MAPK in striatal synaptosomes (data not shown). These results support the idea that $\mathrm{p} 38$ MAPK is involved in IL-1 $\beta$ - or TNF- $\alpha$-stimulated SERT activity in brain.

IL-1 $\beta$ Stimulation of 5-HT Uptake is Blocked by IL-1ra in Mouse Synaptosomes

To evaluate whether the cytokine stimulation of SERT activity in brain is mediated by cytokine receptors, synaptosomes from both midbrain and striatum of mouse

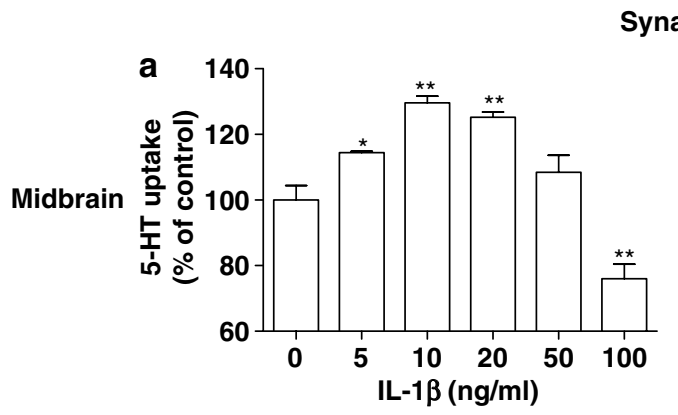

Synaptosomes
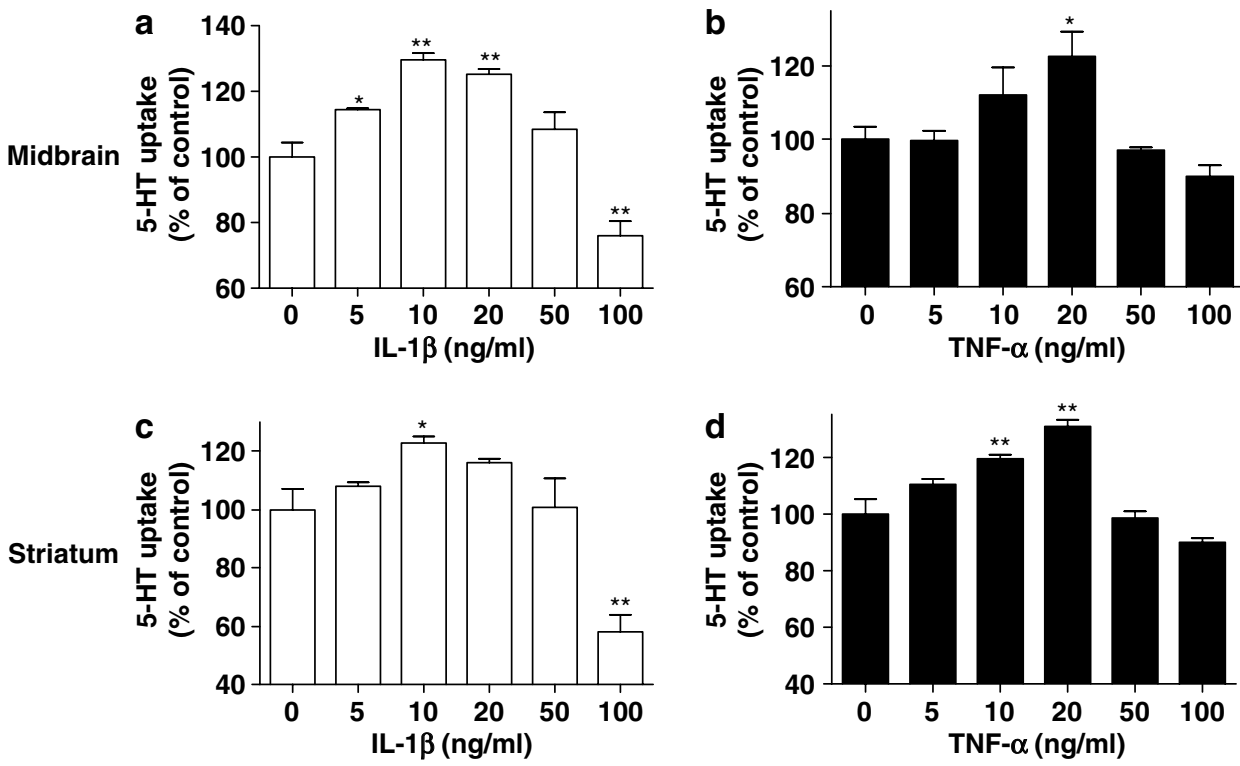

Figure 8 Effects of IL-I $\beta$ and TNF- $\alpha$ on $5-H T$ uptake in mouse synaptosomes. Synaptosomes were preincubated at $37^{\circ} \mathrm{C}$ for 10 min before the cytokine treatment. IL-I $\beta$ or TNF- $\alpha$ at varying concentrations was incubated with synaptosomes for 10 min before a 5 min uptake assay. (a) IL- I $\beta$ effect on midbrain synaptosomes. (b) Influence of TNF- $\alpha$ on 5-HT uptake in midbrain synaptosomes. (c) Effect of IL-I $\beta$ on SERT activity in striatal synaptosomes. (d) Influence of TNF- $\alpha$ on $5-H T$ uptake in striatal synaptosomes. Values are expressed as the mean of at least three experiments \pm SEM. $* p<0.05$, $* * P<0.01$ vs respective controls (one-way ANOVA, Dunnett). 

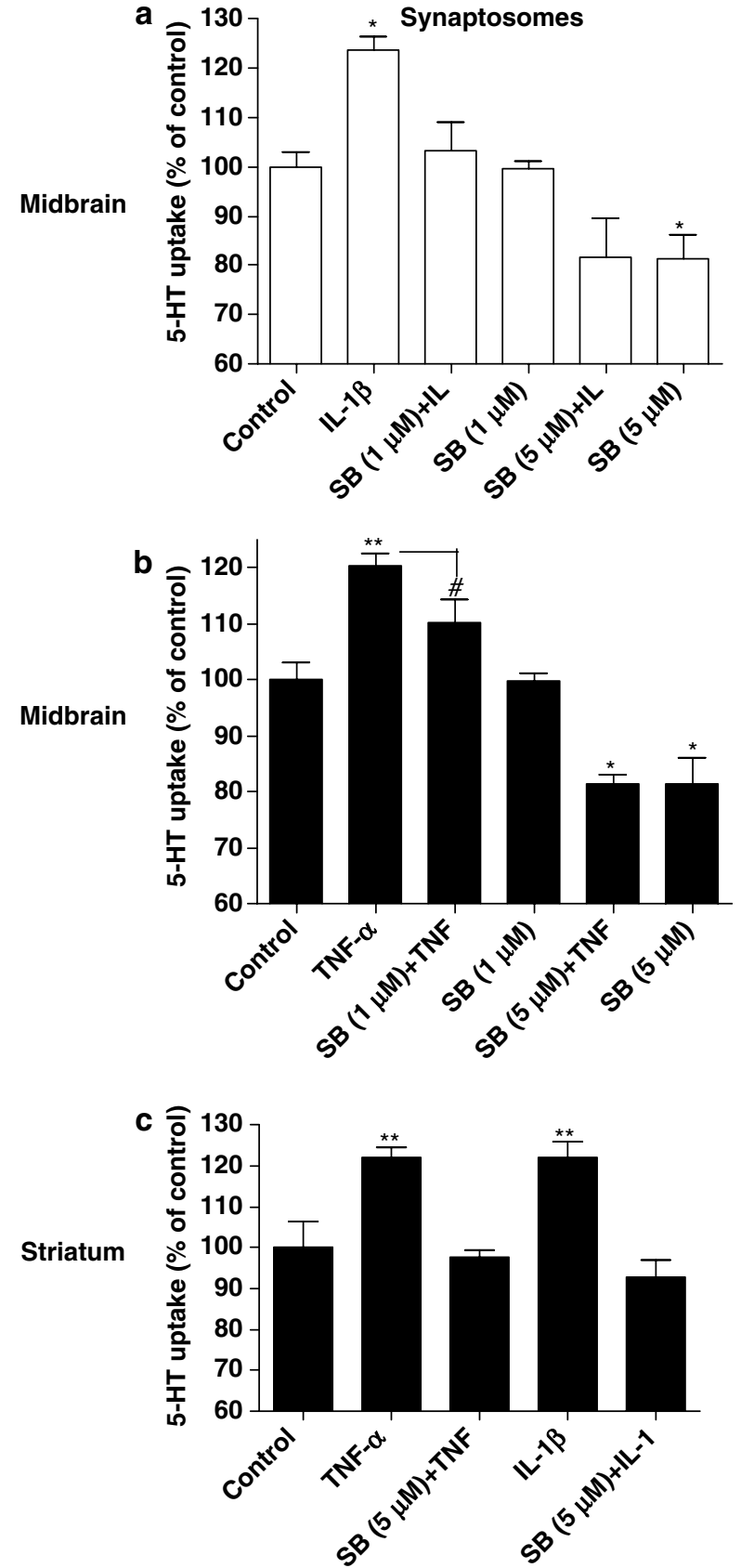

Figure 9 Effects of SB203580 on IL-I $\beta$ - or TNF- $\alpha$-stimulated 5 -HT uptake in mouse synaptosomes. Synaptosomes were incubated with the specific p38 MAPK inhibitor SB203580 or vehicle for $10 \mathrm{~min}$, followed by treatment with IL-I $\beta(\mid 0 \mathrm{ng} / \mathrm{ml})$ or TNF- $\alpha(20 \mathrm{ng} / \mathrm{ml})$ for $10 \mathrm{~min}$. (a) IL-I $\beta$ stimulation of $5-\mathrm{HT}$ uptake in midbrain synaptosomes was blocked by SB203580 at I and $5 \mu \mathrm{M}$. (b) Effect of SB203580 on TNF- $\alpha$-induced 5-HT transport in midbrain synaptosomes. (c) SB203580 at $5 \mu \mathrm{M}$ blocked the effect of both $\mathrm{IL}-\mathrm{I} \beta$ and TNF- $\alpha$ in striatal synaptosomes. Values are expressed as mean values $(n=4) \pm$ SEM. $* p<0.05$, *** $p<0.0$ I vs respective control; ${ }^{\#}<<0.05$ vs TNF- $\alpha$ (two-way ANOVA).

were treated with IL-1 $\beta$ and/or IL-1ra, the antagonist at IL-1 receptors. Consistent with the results from RN46A cells, IL-1 $\beta$ pretreatment of synaptosomes from both midbrain and striatum increased the 5-HT uptake, effects that were abolished by IL-1ra at a concentration that did not affect the basal SERT activity. In contrast, anisomycin stimulation of
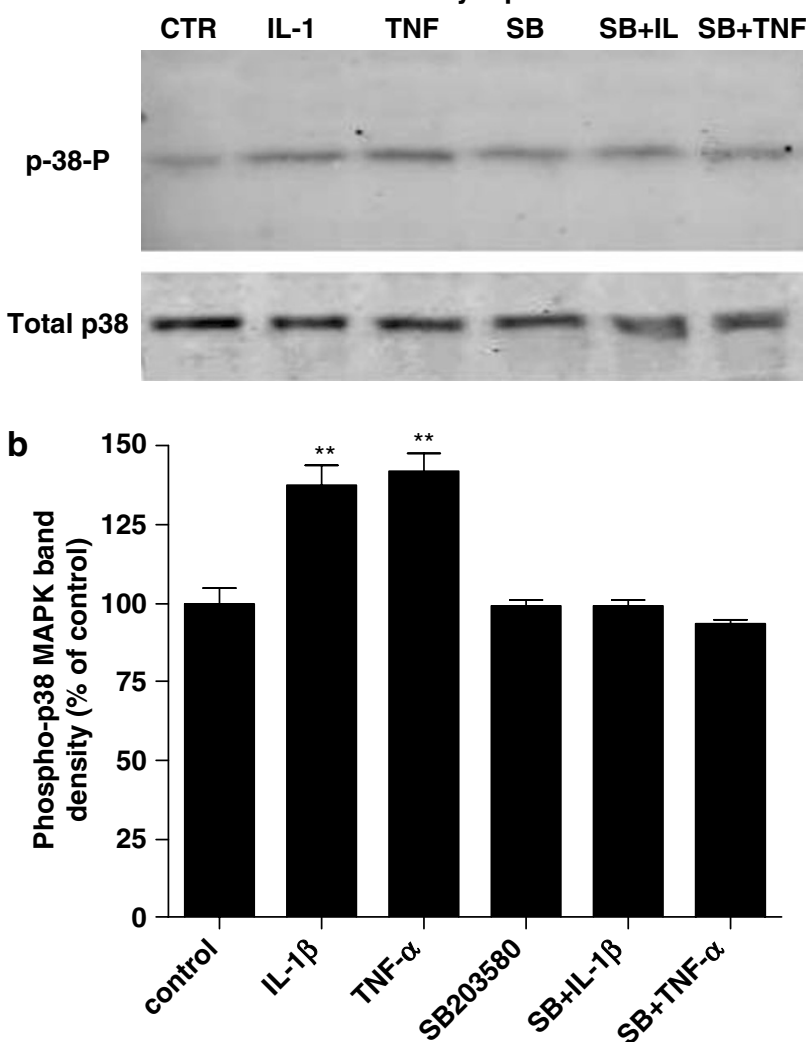

Figure $10 \quad \mathrm{LL}-1 \beta$ and TNF- $\alpha$ activate $\mathrm{p} 38$ MAPK in mouse synaptosomes. Midbrain synaptosomes were prepared as described in Materials and methods. Synaptosomes were treated with vehicle (assay buffer) or SB203580 $(5 \mu \mathrm{M})$ for 10 min followed by 10 min treatment with IL-I $\beta$ or TNF- $\alpha$ (I0 and $20 \mathrm{ng} / \mathrm{ml}$, respectively). The synaptosomes were then processed for activated and total p38 MAPK immunoblots. (a) Representative blots of dual-phosphorylated (top) and total p38 MAPK (bottom). (b) Average values of activated p38 MAPK immunoblots from densitometry experiments $(n=3)$. Values are expressed as the mean \pm SEM. *** $p<0.01$ vs vehicle (one-way ANOVA, Dunnett).

5-HT uptake was not affected by IL-1ra (Figure 11). These data further indicate that IL-1 receptors are critical in mediating IL-1 $\beta$ stimulation of $\mathrm{p} 38$ MAPK and SERT activity.

\section{DISCUSSION}

The influence of cytokines on CNS processing and their potential role in psychiatric disorders has drawn increased scientific attention over the years. In the current study, we found that the proinflammatory cytokines, IL-1 $\beta$ and TNF$\alpha$, acutely stimulate SERT activity in both the raphe cultured cell line and in mouse synaptosomal preparations. This finding supports our hypothesis that proinflammatory cytokines might acutely alter SERT activity in CNS serotonergic neurons, providing a mechanism by which cytokines can modulate serotonergic signaling, and influence emotional cognitive processing. The similarity of the cytokine effects on SERT in midbrain and striatal synaptosomes suggests a consistent effect of these cytokines on SERT over the entirety of the serotonergic neuron, acting to 

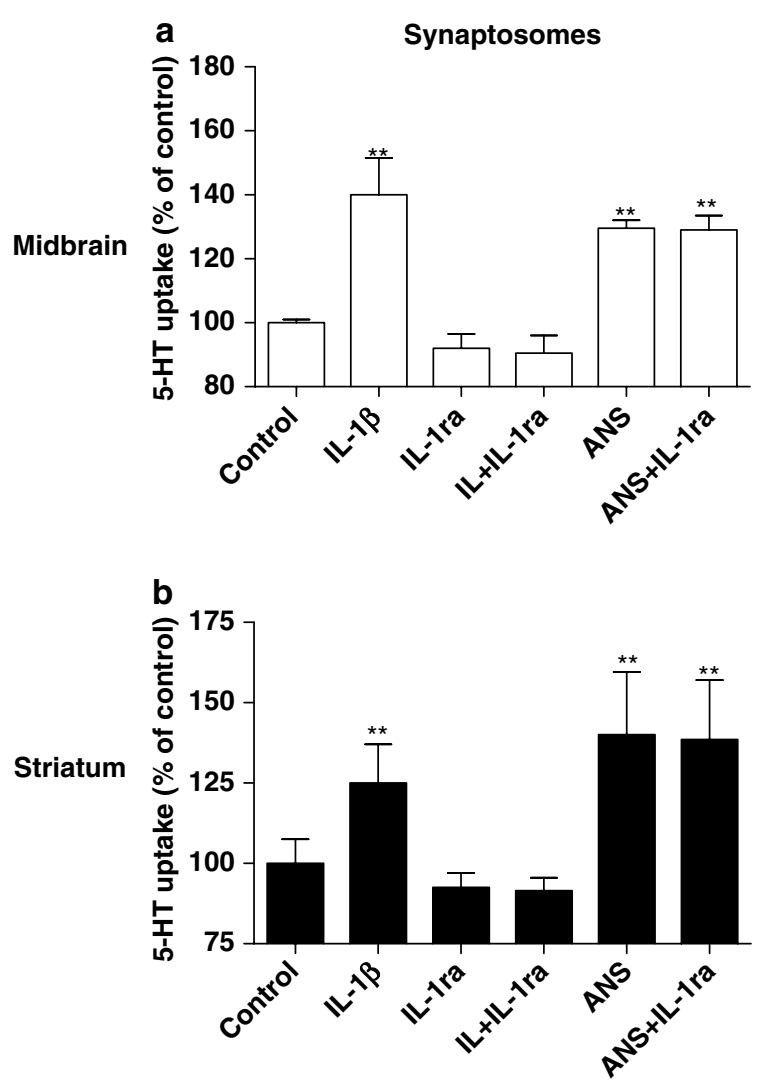

Figure II Effect of IL-Ira on IL-I $\beta$-induced 5-HT uptake in mouse synaptosomes. Synaptosomes from either midbrain or striatum were treated for $10 \mathrm{~min}$ with the IL-I receptor antagonist IL-Ira or vehicle, followed by IL-I $\beta$ (I 0 min) or anisomycin ( $10 \mathrm{~min}$ ) treatment. IL-I ra (I $0 \mathrm{ng} /$ $\mathrm{ml}$ ) completely blocked IL-I $\beta$ - but not anisomycin-induced $5-\mathrm{HT}$ uptake in both (a) midbrain and (b) striatum. Values are expressed as mean values $(n=3) \pm$ SEM. ${ }^{*} * p<0.01$ vs control (one-way ANOVA, Dunnett). ANS: anisomycin.

reduce extracellular 5-HT concentrations in both the perisomatodendritic and distal terminal fields. In the case of IL- $1 \beta$, we confirmed that this stimulation was mediated through an IL-1 receptor present in both the RN46A raphe cell line and on terminals in midbrain and striatal synaptosomes. IL-1 $\beta$ and TNF- $\alpha$ do not exhibit these effects on 5-HT uptake in human platelets (data not shown), which have high levels of SERT, suggesting that the presence of the transporter alone is not sufficient for cytokine inducibility. However, the underlying mechanism proposed here, p38 MAPK activation, does augment platelet SERT activity (Zhu et al, 2005), suggesting that other peripheral cytokines having the capacity to stimulate p38 MAPK might target these formed blood elements.

SB203580 completely abolished IL- $1 \beta$ stimulation of SERT activity in both preparations, but only partially blocked TNF- $\alpha$-induced 5-HT transport, indicating that while both cytokines activate p38 MAPK, TNF- $\alpha$ has an additional mode of enhancing transport. As confirmation of p38 MAPK involvement, we demonstrated that stimulation of 5 -HT transport by IL- $1 \beta$ and TNF- $\alpha$ was paralleled by the activation of p38 MAPK, with increased levels of dualphosphorylated p38 MAPK - an effect that was blocked by SB203580 in both cases.
As predicted from studies with the p38 MAPK activator anisomycin (Zhu et al, 2005), both IL-1 $\beta$ and TNF- $\alpha$ increased the apparent affinity of 5-HT for SERT. TNF- $\alpha$ additionally increased the $V_{\max }$ of this interaction. Kinetic assays showed that SB203580 blocked the changes in $K_{\mathrm{m}}$ induced by IL- $1 \beta$ and TNF- $\alpha$, but, at concentrations that do not impact basal SERT activity, it did not impact the TNF- $\alpha$ induced increase in $V_{\max }$, consistent with an independent mode of action for this latter cytokine. Regardless, these data confirm that p38 MAPK participates in the acute regulation of SERT activity by IL- $1 \beta$ and TNF- $\alpha$, with IL- $1 \beta$ stimulating SERT intrinsic activity and TNF- $\alpha$ enhancing both intrinsic activity and the surface density of the transporter. Alterations in SERT trafficking through PKCor PKG-related mechanisms (Zhu et al, 2004; Qian et al, 1997 ) could potentially play a role in the TNF- $\alpha$-induced increase in SERT density. Further studies are needed to define the p38 MAPK-independent mechanism by which TNF- $\alpha$ augments 5 -HT uptake.

The parameters for activation of SERT did differ in the two preparations. Both IL- $1 \beta$ and TNF- $\alpha$ produced greater activation of SERT in RN46A cells (70-80\%) as compared to the synaptosomal preparations (20-40\%); however, higher concentrations and longer incubation times were required for optimal stimulation in the RN46A cells. There are a number of possible explanations for these differences. First, the process of preparing the synaptosomes, itself, elevates basal p38 MAPK activity (data not shown). This may have reduced the percentage increase inducible by cytokines in this preparation. RN46A cells are immature immortalized cells derived from rat raphe neurons, whereas our synaptosomes were derived from adult mouse brain. Additionally, as the RN46A cells do not form neurites under the conditions of these experiments, our findings with this preparation may reflect processes representative of cytokine interactions at somatodendritic regions of the serotonergic neuron. In contrast, the serotonergic response in synaptosomes might better represent cytokine interactions at serotonergic terminals. Finally, it should be noted that our synaptosomal preparation included non-serotonergic terminals. We cannot rule out the possibility that IL- $1 \beta$ and TNF- $\alpha$ acted at non-serotonergic terminals to induce changes in 5-HT uptake via a trans-synaptic process having different parameters of activation.

Previous studies using JAR choriocarcinoma cells have shown that longer-term exposure to either IL-1 $\beta$ (Ramamoorthy et al, 1995) or TNF- $\alpha$ (Mõssner et al, 1998) will increase 5-HT uptake via an increase in transporter density. These effects, however, required prolonged exposure $-16 \mathrm{~h}$ in the case of IL- $1 \beta$ and $48 \mathrm{~h}$ in the case of TNF- $\alpha$. For IL- $1 \beta$, the increase was attributed to an increase in production and/or stability of SERT mRNA (Ramamoorthy et al, 1995). Exposing this cell preparation to shorter durations $(1-4 \mathrm{~h}$ for IL- $1 \beta ; 24 \mathrm{~h}$ for TNF- $\alpha$ ) produced no significant change in 5-HT uptake. By contrast, the cytokine-induced increase in uptake in our studies involved transcription-independent, short-term modulation of serotonin uptake via catalytic activation of the transporter, occurring within 10-20 min of exposure, and resolving within 20-60 min.

The short duration of cytokine effects in these experiments, relative to the more prolonged elevated circulating 
cytokine levels associated with human illness, raises a question as to the functional significance of the acute effects demonstrated here. Although it is conceivable that the timelimited nature of SERT activation in these experiments was a product of our methodology (ie these cytokines might induce more prolonged activation of SERT in vivo), it is tempting to consider that the brevity of this effect reflects the capability of time-limited cytokine exposure to induce short-term reductions in 5-HT availability. Both TNF- $\alpha$ and IL-1 $\beta$ mRNA and protein are known to be present in specific CNS neuronal populations (Breder et al, 1988, 1993; Ignatowski and Spengler, 1994; Ignatowski et al, 1997), and receptors for these cytokines have differential brain regional distributions (Farrar et al, 1987; Takao et al, 1990; Ban et al, 1991; Kinouchi et al, 1991; Cunningham et al, 1992). Brief local exposure to these cytokines results in both documented neuronal and behavioral effects. IL-1 $\beta$ receptors are found in the medial hypothalamus, where they are colocalized with 5-HT-2C receptors (Hassanain et al, 2005). Microinjection of low concentrations of IL- $1 \beta$ into this region facilitates short-term defensive rage expression in the cat, an effect blocked by a 5-HT-2 antagonist (Hassanain et al, 2005). Brief in vivo exposure of orbitoprefrontal neurons to IL- $1 \beta$ is associated with either hyperpolarizing or depolarizing potentials in different neuronal populations (Lukáts et al, 2005). In guinea-pig brain slice preparations, IL- $1 \beta$ induces a rapid reduction in the firing rates of neurons in the serotonergic dorsal raphe nucleus (DRN; Manfridi et al, 2003), an area replete with IL receptors (Cunningham et al, 1992). The reduced firing rate is associated with a hyperpolarization of the neurons that is rapidly reversed with washout of IL- $1 \beta$. Consistent with this effect, when microinjected into the DRN in vivo, IL-1 $\beta$ induces sleep without rapid eye movements (Manfridi et al, 2003), early in the sleep cycle.

Similarly, short-term exposure of hippocampal neurons to TNF- $\alpha$ (15-30 $\mathrm{min})$ has been found to induce endocytosis of GABA-A receptors and increase trafficking of excitatory AMPA receptors to the plasma membrane (Stellwagen et al, 2005). TNF- $\alpha$ will also inhibit norepinephrine (NE) release in a manner dependent on alpha-2 adrenergic receptor activation (Ignatowski et al, 1997). In the aggregate, these findings suggest that short-term exposure to IL- $1 \beta$ or TNF- $\alpha$ induces rapid neuronal plasticity, independent of the effects associated with long-term exposure that might be seen in the setting of chronically elevated peripheral cytokines. These findings are consistent with the possibility that these cytokines, released locally, may act in the CNS as short-term neuromodulators that influence local synaptic 5-HT availability.

Irrespective of whether acute changes in SERT activity occur at the initial stages of prolonged cytokine elevations or are a result of shorter, acute fluctuations in CNS cytokine levels, our study provides first evidence that proinflammatory cytokines can alter SERT function acutely in preparations of serotonergic neuronal tissue, and further implicates a p38 MAPK-linked pathway in SERT regulation. Additionally, our synaptosomal findings suggest that functional p38 MAPK in distal terminals has the capability to regulate local 5-HT concentrations, independent of cellular processing occurring in the neuronal soma. Such a functional localization suggests a potential role for p38 MAPK in real-time modulation of neuronal activity at serotonergic terminals.

Recently, we established that multiple human SERT coding variants are refractory to p38 MAPK stimulation, effects also observed in primary lymphocytes derived from autistic probands (Prasad et al, 2005). Our studies suggest that CNS sites of SERT expression in these subjects would also lack flexibility for cytokine-triggered changes in 5-HT uptake. The detailed molecular mechanism of cytokineinduced SERT activity requires more study. Potential mechanisms may involve p38 MAPK-dependent alterations in phosphorylation states of SERT and associated proteins. Additional in vivo studies should be undertaken and may provide new perspectives on the relevance of cytokines for emotional cognitive processing, as well as the potential for the development of novel compounds that might target these signaling pathways as treatments for psychiatric disorders.

\section{ACKNOWLEDGEMENTS}

This study was supported by NARSAD award to C-B Z, NIDA DA07390 to RDB, and the OCD/TS Program to WAH. We thank Ana Maria Carneiro for her help in human platelet experiment, Qiao Han for cell culture support, Paul MacDonald for figure editing, and Tammy Jessen for her general lab maintenance.

\section{REFERENCES}

Ansah TA, Ramamoorthy S, Montanez S, Daws LC, Blakely RD (2003). $\mathrm{Ca}^{2+}$-dependent inhibition of synaptosomal serotonin transport by the alpha 2-adrenoceptor agonist 5-bromo- $\mathrm{N}$ [4,5-dihydro-1H-imidazol-2-yl]-6-quinoxalinamine (UK14304). J Pharmacol Exp Ther 305: 956-965.

Ban E, Milon G, Prudhomme N, Fillion G, Haour F (1991). Receptors for interleukin-1 (alpha and beta) in mouse brain: mapping and neuronal localization in hippocampus. Neuroscience 43: 21-30.

Barker EL, Blakely RD (1995). Norepinephrine and serotonin transporters: molecular targets of antidepressant drugs. In: Bloom FE, Kupfer DJ (eds). Psychopharmacology: The Fourth Generation of Progress. Raven Press, Ltd: New York. pp 321-333.

Bette M, Kaut O, Schafer MK, Weihe E (2003). Constitutive expression of p55TNFR mRNA and mitogen-specific up-regulation of TNF alpha and p75TNFR mRNA in mouse brain. J Comp Neurol 465: 417-430.

Blakely RD, Defelice LJ, Galli A (2005). Biogenic amine neurotransmitter transporters: just when you thought you knew them. Physiology (Bethesda) 20: 225-231.

Botchkina GI, Meistrell Jr ME, Botchkina IL, Tracey KJ (1997). Expression of TNF and TNF receptors (p55 and p75) in the rat brain after focal cerebral ischemia. Mol Med 3: 765-781.

Breder CD, Dinarello CA, Saper CB (1988). Interleukin-1 immunoreactive innervation of the human hypothalamus. Science 240: 321-324.

Breder CD, Tsujimoto M, Terano Y, Scott DW, Saper CB (1993). Distribution and characterization of tumor necrosis factoralpha-like immunoreactivity in the murine central nervous system. J Comp Neurol 337: 543-567.

Brockhaus M, Loetscher H (1990). Identification of two types of TNF receptors on human cell line by monoclonal antibodies. Proc Natl Acad Sci USA 87: 3127. 
Caspi A, Sugden K, Moffitt TE, Taylor A, Craig IW, Harrington H et al (2003). Influence of life stress on depression: moderation by a polymorphism in the 5-HTT gene. Science 301: 386-389.

Cho L, Tsunoda M, Sharma RP (1999). Effects of endotoxin and tumor necrosis factor alpha on regional brain neurotransmitters in mice. Nat Toxins 7: 187-195.

Clerk A, Harrison JG, Long CS, Sugden PH (1999). Proinflammatory cytokines stimulate mitogen-activated protein kinase subfamilies, increase phosphorylation of c-Jun and ATF2 and upregulate c-Jun protein in neonatal rat ventricular myocytes. J Mol Cell Cardiol 31: 2087-2099.

Cunningham Jr ET, Wada E, Carter DB, Tracey DE, Battey JF, De Souza EB (1992). In situ histochemical localization of type I interleukin-1 receptor messenger RNA in the central nervous system, pituitary, and adrenal gland of the mouse. J Neurosci 12: $1101-1114$.

Dantzer R (2001). Cytokine-induced sickness behavior: mechanisms and implications. Ann NY Acad Sci 933: 222-234.

Dunn AJ (1992). Endotoxin-induced activation of cerebral catecholamine and serotonin metabolism: comparison with interleukin-1. J Pharmacol Exp Ther 261: 964-969.

Eaton MJ, Whittemore SR (1996). Autocrine BDNF secretion enhances the survival and serotonergic differentiation of raphe neuronal precursor cells grafted into the adult rat CNS. Exp Neurol 140: 105-114.

Farrar WL, Kilian PL, Ruff MR, Hill JM, Pert CB (1987). Visualization and characterization of interleukin 1 receptors in brain. J Immunol 39: 459-463.

Hall SR, Smith AP (1996). Behavioural effects of infectious mononucleosis. Neuropsychobiology 33: 202-209.

Hassanain M, Bhatt S, Zalcman S, Siegel A (2005). Potentiating role of interleukin-1beta (IL-1beta) and IL-1beta type 1 receptors in the medial hypothalamus in defensive rage behavior in the cat. Brain Res 1048: 1-11.

Hohmann HP, Remy R, Brockhaus M, van Loon APGM (1989). Two different cell types have different major receptors for human tumor necrosis factor (TNF- $\alpha$ ). J Biol Chem 264: 14927.

Ignatowski TA, Noble BK, Wright JR, Gorfien JL, Heffner RR, Spengler RN (1997). Neuronal-associated tumor necrosis factor (TNF alpha): its role in noradrenergic functioning and modification of its expression following antidepressant drug administration. J Neuroimmunol 79: 84-90.

Ignatowski TA, Spengler RN (1994). Tumor necrosis factor-alpha: presynaptic sensitivity is modified after antidepressant drug administration. Brain Res 665: 293-299.

Kent S, Bret-Dibat JL, Kelley KW, Dantzer R (1996). Mechanisms of sickness-induced decreases in food-motivated behavior. Neurosci Biobehav Rev 20: 171-175.

Kinouchi K, Brown G, Pasternak G, Donner DB (1991). Identification and characterization of receptors for tumor necrosis factor-alpha in the brain. Biochem Biophys Res Commun 181: $1532-1538$

Li YP, Chen Y, John J, Moylan J, Jin B, Mann DL et al (2005). TNFalpha acts via p38 MAPK to stimulate expression of the ubiquitin ligase atrogin1/MAFbx in skeletal muscle. FASEB J 19: 362-370.

Lukáts B, Egyed R, Karadi Z (2005). Single neuron activity changes to interleukin-1beta in the orbitofrontal cortex of the rat. Brain Res 1038: 243-246.

Maes M (1999). Major depression and activation of the inflammatory response system. Adv Exp Med Biol 461: 25-46.

Manfridi A, Brambilla D, Bianchi S, Mariotti M, Opp MR, Imeri L (2003). Interleukin-1beta enhances non-rapid eye movement sleep when microinjected into the dorsal raphe nucleus and inhibits serotonergic neurons in vitro. Eur J Neurosci 18 1041-1049.

Meijer A, Zakay-Rones Z, Morag A (1988). Post-influenzal psychiatric disorder in adolescents. Acta Psychiatr Scand 78: 176-181.
Miller KJ, Hoffman BJ (1994). Adenosine A3 receptors regulate serotonin transport via nitric oxide and cGMP. J Biol Chem 269: 27351-27356.

Mittleman BB, Castellanos FX, Jacobsen LK, Rapoport JL, Swedo SE, Shearer GM (1997). Cerebrospinal fluid cytokines in pediatric neuropsychiatric disease. J Immunol 159: 2994-2999.

Mõssner R, Heils A, Stober G, Okladnova O, Daniel S, Lesch KP (1998). Enhancement of serotonin transporter function by tumor necrosis factor alpha but not by interleukin-6. Neurochem Int 33: 251-254.

Murphy DL, Uhl GR, Holmes A, Ren-Patterson R, Hall FS, Sora I et al (2003). Experimental gene interaction studies with SERT mutant mice as models for human polygenic and epistatic traits and disorders. Genes Brain Behav 2: 350-364.

Nestler EJ, Hyman SE, Malenka RC (2001). Serotonin, acetylcholine, and histamine. In: Nestler EJ, Hyman SE, Malenka RC (eds). Molecular Neuropharmacology, A Foundation for Clinical Neuroscience. McGraw-Hill: New York. pp 191-211.

New L, Han J (1998). The p38 MAP kinase pathway and its biological function. Trends Cardiovasc Med 8: 220-228.

O'Neill LA, Dinarello CA (2000). The IL-1 receptor/toll-like receptor superfamily: crucial receptors for inflammation and host defense. Immunol Today 21: 206-209.

Ozaki N, Goldman D, Kaye WH, Plotnicov K, Greenberg BD, Lappalainen J et al (2003). Serotonin transporter missense mutation associated with a complex neuropsychiatric phenotype. Mol Psychiatry 8: 933-936.

Palazzolo DL, Quadri SK (1992). Interleukin-1 inhibits serotonin release from the hypothalamus in vitro. Life Sci 51: 1797-1802.

Pantouli E, Boehm MM, Koka S (2005). Inflammatory cytokines activate p38 MAPK to induce osteoprotegerin synthesis by MG-63 cells. Biochem Biophys Res Commun 329: 224-249.

Pollak Y, Ovadia H, Goshen I, Gurevich R, Monsa K, Avitsur R et al (2000). Behavioral aspects of experimental autoimmune encephalomyelitis. J Neuroimmunol 104: 31-36.

Prasad HC, Zhu CB, McCauley JL, Samuvel DJ, Ramamoorthy S, Shelton RC et al (2005). Human serotonin transporter variants display altered sensitivity to protein kinase $G$ and p38 mitogenactivated protein kinase. Proc Natl Acad Sci USA 102: 11545-11550.

Qian Y, Galli A, Ramamoorthy S, Risso S, DeFelice LJ, Blakely RD (1997). Protein kinase C activation regulates human serotonin transporters in HEK-293 cells via altered cell surface expression. J Neurosci 17: 45-57.

Ramamoorthy S, Blakely RD (1999). Phosphorylation and sequestration of serotonin transporters differentially modulated by psychostimulants. Science 285: 763-766.

Ramamoorthy S, Giovanetti E, Qian Y, Blakely RD (1998). Phosphorylation and regulation of antidepressant-sensitive serotonin transporters. J Biol Chem 273: 2458-2466.

Ramamoorthy S, Ramamoorthy JD, Prasad PD, Bhat GK, Mahesh VB, Leibach FH et al (1995). Regulation of the human serotonin transporter by interleukin-1 beta. Biochem Biophys Res Commun 216: $560-567$.

Rivest S, Lacroix S, Vallieres L, Nadeau S, Zhang J, Laflamme N (2000). How the blood talks to the brain parenchyma and the paraventricular nucleus of the hypothalamus during systemic inflammatory and infectious stimuli. Proc Soc Exp Biol Med 223: 22-38.

Saklatvala J (2004). The p38 MAP kinase pathway as a therapeutic target in inflammatory disease. Curr Opin Pharmacol 4: 372-377.

Schiepers OJ, Wichers MC, Maes M (2005). Cytokines and major depression. Prog Neuropsychopharmacol Biol Psychiatry 29: 201-217.

Sheng WS, Hu S, Ding JM, Chao CC, Peterson PK (2001). Cytokine expression in the mouse brain in response to immune activation by Corynebacterium parvum. Clin Diagn Lab Immunol 8: 446-448. Sims JE, March CJ, Cosman D, Widmer MB, MacDonald HR, McMahan CJ et al (1988). cDNA expression cloning of the IL-1 
receptor, a member of the immunoglobulin superfamily. Science 241: $585-589$.

Stauber GB, Aiyer RA, Aggarwal BB (1988). Human tumor necrosis factor-alpha receptor. Purification by immunoaffinity chromatography and initial characterization. J Biol Chem 263: 19098-19104.

Stellwagen D, Beattie EC, Seo JY, Malenka RC (2005). Differential regulation of AMPA receptor and GABA receptor trafficking by tumor necrosis factor-alpha. J Neurosci 25: 3219-3228.

Sutcliffe JS, Delahanty RJ, Prasad HC, McCauley JL, Han Q, Jiang L et al (2005). Allelic heterogeneity at the serotonin transporter locus (SLC6A4) confers susceptibility to autism and rigidcompulsive behaviors. Am J Hum Genet 77: 265-279.

Takao T, Tracey DE, Mitchell WM, De Souza EB (1990). Interleukin-1 receptors in mouse brain: characterization and neuronal localization. Endocrinology 127: 3070-3078.

Tuglu C, Kara SH, Caliyurt O, Vardar E, Abay E (2003). Increased serum tumor necrosis factor-alpha levels and treatment response in major depressive disorder. Psychopharmacology (Berl) 170: 429-433.

Yirmiya R, Pollak Y, Morag M, Reichenberg A, Barak O, Avitsur R et al (2000). Illness, cytokines, and depression. Ann NY Acad Sci 917: 478-487.

Yirmiya R, Weidenfeld J, Pollak Y, Morag M, Morag A, Avitsur R et al (1999). Cytokines, 'depression due to a general medical condition,' and antidepressant drugs. Adv Exp Med Biol 461: 283-316.

Zhu CB, Carneiro AM, Dostmann WR, Hewlett WA, Blakely RD (2005). p38 MAPK activation elevates serotonin transport activity via a trafficking-independent, protein phosphatase 2A-dependent process. J Biol Chem 280: 15649-15658.

Zhu CB, Hewlett WA, Feoktistov I, Biaggioni I, Blakely RD (2004). Adenosine receptor, protein kinase $G$, and p38 mitogenactivated protein kinase-dependent up-regulation of serotonin transporters involves both transporter trafficking and activation. Mol Pharmacol 65: 1462-1474. 